2. To: (Receiving Organization) Distribution

5. Proj./Prog./Dept./Div.:

Tank Waste Information

Network System II

(TWINS2)/Waste

Management/TBP/Process

Engineering

8. Originator Remarks:

This document.. is being released into the supporting document. system for retrievability purposes.

11. Receiver Remarks: 11A. Design Baseline Document? [] Yes $[X]$ No For release.

3. From: (Originating organization)
Data Management/Technical
Basis and Planning

M. R. Adams Engr.:
7. Purchase Order No.:

$\mathrm{N} / \mathrm{A}$

9. Equip./Component No.:

$\ldots \quad ; \cdots \cdots \cdots \cdots+N / A$

10. System/Bldg./Facility: $\mathrm{N} / \mathrm{A}$

12. Major Assm. Dwg. No.:

N/A

13. Permit/Permit Application No.: N/A

14. Required Response Date: 04/15/98

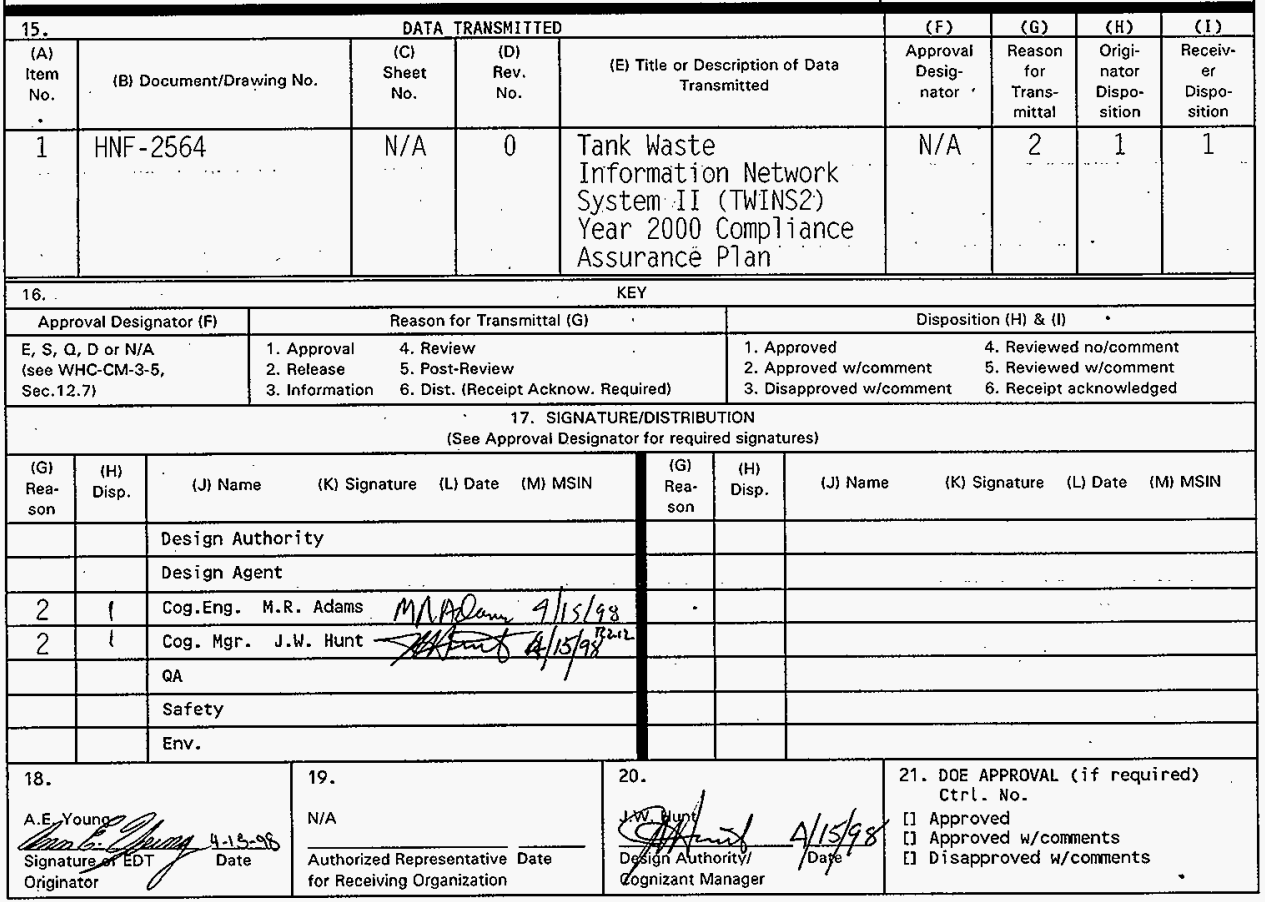




\title{
Tank Waste Information Network System II (TWINS2) Year 2000 Compliance Assurance Plan
}

\author{
M. R. Adams \\ Lockheed Martin Hanford, Corp., Richland, WA 99352 \\ U.S. Department of Energy Contract DE-AC06-87RL10930
}

EDT/ECN: EDT-622436 UC: 2070

Org Code: 7A110 Charge Code: N4G5B

B\&R Code: EW 3120074 Total Pages: 9

Key Words: Tank Waste, Information. Network. TWINS2, Year 2000, Compliance Assurance Plan, Plan

Abstract: N/A

TRADEMARK DISCLAIMER. Reference herein to any specific commercial product, process, or service by trade name, trademark, manufacturer, or otherwise, does not necessarily constitute or imply its endorsement, recommendation, or favoring by the United States Government or any agency thereof or its contractors or subcontractors.

Printed in the United States of America. To obtain copies of this document, contact: WHC/BCS Document Control Services, P.0. Box 1970, Mailstop H6-08, Richland WA 99352, Phone (509) 372-2420; Fax (509) 376-4989.
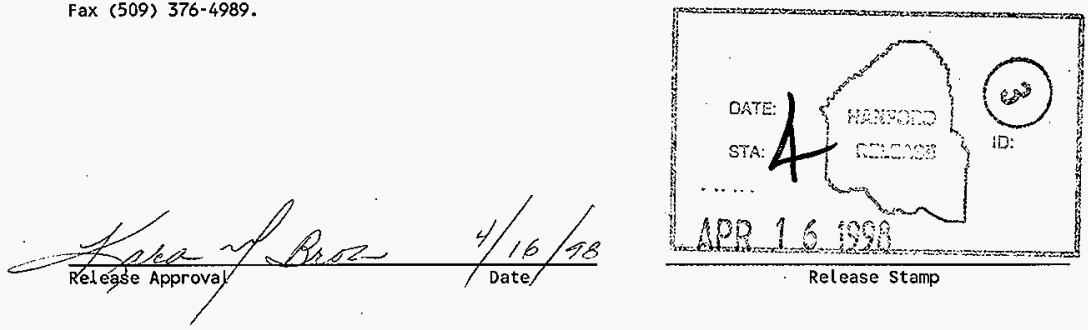

Approved for Public Release 


\title{
Tank Waste Information Network System II (TWINS2) Year 2000 Compliance Assurance Plan
}

\author{
M. R. Adams \\ Lockheed Martin Hanford Corporation
}

Date Published

April 1998

Prepared for the U.S. Department of Energy Assistant Secretary for Environmental Management

\section{Fluor Daniel Hanford, Inc.}

P.O. Box 1000

Richland, Washington

Hanford Management and Integration Contractor for the

U.S. Department of Energy under Contract DE-ACO6-96RL13200

Copyright Licene By accoptance of this article, the publisher and/or recipient ackrowlodges the

U.S. Government's right to retain a nonexclusive, royatty-free license in and to any copyright covering this paper. 
HNF-2564

Rev. 0

This page intentionally left blank. 
HNF-2564 Rev. 0

\section{CONTENTS}

$1.0 \mathrm{sCOPE} \ldots \ldots \ldots \ldots \ldots \ldots \ldots$

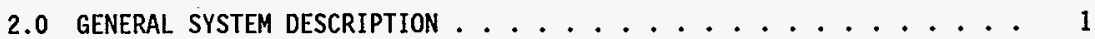

3.0 GENERAL CONDITION OF COMPLIANCE .............. 2

4.0 TEST CASE LIST . . . . . . . . . . . . . . . . 3

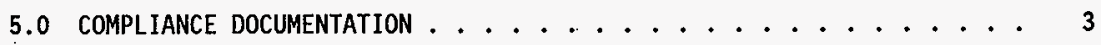

6.0 COMPLIANCE TASK LIST AND SCHEDULE ............. 4

7.0 RESPONSIBILITIES ...................... 4 
HNF-2564 Rev. 0

This page intentionally left blank. 


\subsection{SCOPE}

The scope of this plan includes the Tank Waste Information Network System II (TWINS2) that contains the following major components: Tank Characterization Database (TCD), Tank Vapor Database (TVD), Data Source Access (DSA), automated Tank Characterization Report, Best-Basis Inventory Model (BBIM), and Tracker (corrective action tracking) function. The automated Tank Characterization. Report application currentiy in development also wil1 reside on the TWINS system as will the BBIM. Critical inputs to TWINS occur from the following databases: Labcore and SACS. Output does not occur from TWINS to these two databases.

\subsection{GENERAL SYSTEH DESCRIPTION}

The TWINS hardware consists of two NT servers recently installed and tested. The software suite consists of the following:

- Microsoft SQL Server 6.5

- Microsoft Access 97

- Microsoft Exce1 97

- Microsoft Word 97

- Lotus Notes 4.5

- Domino Web Server 4.5.2

- CGI Script (for web interface).

The following table indicates the software associated with each major component of the TWINS system.

\begin{tabular}{|c|c|c|c|c|c|c|c|}
\hline WIMS Sortrare and & 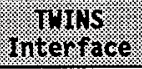 & OSH. & 6 & \%O & $8 B 13$ & HGo & Wharen \\
\hline SQL Server & & & $\mathbf{x}$ & $\mathrm{x}$ & $\mathrm{x}$ & $x$ & \\
\hline Access 97 & & & $x$ & & $x$ & $x$ & \\
\hline Exce1 97 & $x$ & & & & & $x$ & \\
\hline Word 97 & & & & & & $x$ & \\
\hline Lotus Notes 4.5 & & $x$ & & & & & - \\
\hline Domino & & $x$ & & & & & \\
\hline Home-grown date functions & $x$ & $\bar{x}$ & $?$ & $?$ & $?$ & & \\
\hline PC TWINS NT Server & & $x$ & & & & $x$ & \\
\hline Kayla NT Server & $x$ & & $x$ & $x$ & $x$ & $x$ & \\
\hline External Data Interfaces & $x$ & & $x$ & & & $x$ & \\
\hline PVCS & & & & & & & $x$ \\
\hline
\end{tabular}


The TWINS system provides entry, storage, report, edit, and network access capabilities for a wide variety of tank characterization data including inventory data, analytical data, sampling data, vapor data, physical properties data for both chemical and radionuclide species. Also, the system provides network and world wide web access to data, documents, visual information, graphics, electronic document templates, standard data reports, and other information including the ability to do key-word and tank specific document searches. The system capabilities are constantly being updated in response to user needs. Loading of tank analytical data is constantly kept up-to-date to comply with Tri-Party Agreement (TPA) requirements. Network access to the data is al so a TPA requirement.

This is a high risk system (rating 175) because the data are used for tank safety evaluations, preparation of Tank Characterization Reports, disposa] program efforts, and TPA compliance.

\subsection{GENERAL CONDITION OF COMPLIANCE}

No significant year 2000 compliance problems have been identified with this system. The system has been upgraded to state-of-the-art software and hardware. However, because analytical data is time dependent (e.g., the dates of sampling and analysis are critical factors in the usefulness of the data) and because the system is high risk, vigorous verification and documentation of compliance is necessary.

The CGI script component of the system (see Section 2.0) has known SACS data date query problems which will require a few hours to fix. The problem will be addressed by moving or replacing the CGI script functions to other software.

In general, the following conditions of compliance shall be verified.

- Al1 representations and uses of year (including century) are free of defects, miscalculations, and misrepresentations.

- The date $9 / 9 / 99$ is accounted for, is properly handled and will not be interpreted as end-of-file, or other status indication.

- The date $12 / 31 / 99$ is accounted for, is properly handled and will not be interpreted as end-of-file, or other status indication.

- The date $1 / 1 / 2000$ is accounted for and properly handled.

- The date $2 / 29 / 2000$ and its surrounding days are accounted for and are properly handled.

- Use of dates or values ' $00^{\prime}$ or ' $99^{\prime}$ in files and/or databases will produce correct results and will not be interpreted as end-of-file, or other status indication. 
- Use of 2-digit year values in files, databases, program logic, operating system calls, and external interfaces have been evaluated, tested, and validated, and will produce reliable and consistent results.

- Prior-year and future-year dates are processed accurately through the entire range of dates expected to be encountered, including dates that span centuries.

\subsection{TEST CASE LIST}

The following minimum test cases will be run and documented to verify system compliance:

- September 8, 1999 to September 9, 1999 (tests 9999)

- December 31, 1999 to January 1, 2000 (change of millennium)

- February 28, 2000 to February 29, 2000 (recognition of leap year)

- February 29, 2000 to March 1, 2000 (does not go to February 30 or 31)

- February 29, 2001 (should create error as 2001 is not a leap year)

- December 30, 2000 to January 1, 2001 (checks for bad leap year calculation)

- December 31, 2000 to January 1, 2001 (shows year 2000 has 366 days).

\subsection{COMPLIANCE DOCUNENTATION}

The following year 2000 compliance documentation shall be prepared for this system:

- Year 2000 Compliance Assurance Plan (this document)

- System Description (hardware and software with version numbers)

- Assessment of Vendor Testing and Documentation (an assessment of vendor supplied year 2000 compliance testing and documentation including results of a review of vendor supplied manuals and certifications)

- Test Case Documentation (includes date and time of each test case listed in Section 4.0, along with verification sign-off by tester and independent witness; includes description of test, test results and documentary evidence of test success) 
- Test Plan for Pacific Northwest National Laboratory (PNNL) Date Functions (primarily relates to CGI software).

\subsection{COMPLIANCE TASK LIST AND SCHEDULE}

\begin{tabular}{|c|c|c|}
\hline Trask then & Duve oate & coments \\
\hline $\begin{array}{l}\text { 1. Prepare, review and issue Year } 2000 \\
\text { Compliance Assurance Plan }\end{array}$ & Apri1 17, 1998 & Initiated \\
\hline 2. Complete system description & April 30, 1998 & \\
\hline $\begin{array}{l}\text { 3. Complete assessment of vendor testing } \\
\text { and documentation }\end{array}$ & May 15, 1998 & \\
\hline 4. Complete test cases for TVD & June 15,1998 & \\
\hline 5. Complete test cases for TCD & June 15,1998 & \\
\hline 6. Complete test cases for autoTCR & June 30,1998 & \\
\hline 7. Complete test cases for BBIM & June 30,1998 & \\
\hline 8. Complete test cases for Tracker & June 30,1998 & \\
\hline 9. Complete test cases for DSA & July 15,1998 & \\
\hline $\begin{array}{l}\text { 10. Review SACS compliance assessment and } \\
\text { identify interface problems }\end{array}$ & When available & \\
\hline $\begin{array}{l}\text { 11. Review Labcore compliance assessment } \\
\text { and identify interface problems }\end{array}$ & When av & \\
\hline $\begin{array}{l}\text { 12. Complete test case documentation for } \\
\text { items } 4 \text { through } 9\end{array}$ & August 15, 1998 & \\
\hline $\begin{array}{l}\text { 13. Prepare contingency plan for SACS } \\
\text { interface (if required) }\end{array}$ & $\begin{array}{l}\text { No later than } \\
\text { August } 30,1998\end{array}$ & \\
\hline 14. Move or replace CGI script functions & $\begin{array}{l}\text { No later than } \\
\text { August } 30,1998\end{array}$ & \\
\hline $\begin{array}{l}\text { 15. Prepare contingency } p l a \text { an for Labcore } \\
\text { interface (if required) }\end{array}$ & $\begin{array}{l}\text { No later than } \\
\text { August } 30,1998\end{array}$ & \\
\hline 16. Sign compliance certification document & September 15, 1998 & \\
\hline
\end{tabular}

\subsection{RESPONSIBILITIES}

The owner of this system is Lockheed Martin Hanford Co., M. R. Adams, lead for TWRS characterization data management. The operator of this system is PNNL, Steve Bobrowski, TWINS project manager. All documents and tests 1 isted above (except item \#1) shall be prepared by PNNL for delivery to and review and approval by LMHC (M. R. Adams). 


\begin{tabular}{|c|c|c|c|c|c|c|}
\hline \multicolumn{7}{|c|}{ DISTRIBUTION SHEET } \\
\hline \multirow[b]{2}{*}{ Distribution } & \multirow{2}{*}{\multicolumn{4}{|c|}{$\begin{array}{l}\text { From } \\
\text { Data Management/Technical } \\
\text { Basis and Planning }\end{array}$}} & \multicolumn{2}{|l|}{ Page 1 of 1} \\
\hline & & & & & \multicolumn{2}{|c|}{ Date $04 / 15 / 98$} \\
\hline \multicolumn{5}{|c|}{ Project Title/Work Order } & \multicolumn{2}{|c|}{ EDT No. EDT-622436 } \\
\hline \multicolumn{5}{|c|}{$\begin{array}{l}\text { HNF-2564, Rev. 0, "Tank Waste Information Network System II } \\
\text { (TWINS2) Year } 2000 \text { Compliance Assurance Plan" }\end{array}$} & \multicolumn{2}{|l|}{ ECN No. N/A } \\
\hline Name & & MSIN & $\begin{array}{c}\text { Text } \\
\text { With } \\
\text { All } \\
\text { Attach. }\end{array}$ & Text Only & $\begin{array}{l}\text { Attach./ } \\
\text { Appendix } \\
\text { Only }\end{array}$ & $\begin{array}{l}\text { EDT/ECN } \\
\text { Only }\end{array}$ \\
\hline $\begin{array}{l}\text { Lockheed Martin Hanford. Corp. } \\
\text { M. R. Adams } \\
\text { R. B. Bass } \\
\text { J. W. Hunt } \\
\text { E. I. Husa } \\
\text { J. G. Kristofzski } \\
\text { J.B. Schaffer } \\
\text { T.C.S.R.C. }\end{array}$ & & $\begin{array}{l}\text { R2-12 } \\
\text { H7-06 } \\
\text { R2-12 } \\
\text { R2-11 } \\
\text { R2-12 } \\
\text { R2-11 } \\
\text { R1-10 }\end{array}$ & $\begin{array}{l}x \\
X \\
x \\
x \\
x \\
x \\
x\end{array}$ & & & \\
\hline $\begin{array}{l}\text { Lockheed Martin Services, Inc. } \\
\text { Central Files }\end{array}$ & & B1-07 & $x$ & & & \\
\hline$\frac{\text { Pacific Northwest Nationa] Labol }}{\text { S. F. Bobrowski }}$ & cory & $K 7-28$ & $x$ & & & \\
\hline
\end{tabular}

